Article

\title{
An Efficient Synthesis of Novel Bioactive Thiazolyl-Phthalazinediones under Ultrasound Irradiation
}

\author{
Fatma S. Elsharabasy ${ }^{1,2}$, Sobhi M. Gomha ${ }^{3}$, Thoraya A. Farghaly ${ }^{3,4, *}$ and Heba S. A. Elzahabi ${ }^{5}$ \\ 1 Department of Chemistry of Natural and Microbial Products, National Research Center, Dokki 12622, Egypt; \\ elsharabasy2000@gmail.com \\ 2 Collage of Science and Humanities, Sattam bin Abdul Aziz University, Alkharj City 11942, Saudi Arabia \\ 3 Department of Chemistry, Faculty of Science, Cairo University, Giza 12613, Egypt; s.m.gomha@gmail.com \\ 4 Department of Chemistry, Faculty of Applied Science, UmmAl-Qura University, \\ Makkah Almukkarramah 21514, Saudi Arabia \\ 5 Department of Pharmaceutical Chemistry, Faculty of Pharmacy (Girls), AlAzhar University, Cairo1 1754, \\ Egypt; helzahabi@yahoo.com \\ * Correspondence: thoraya-f@hotmail.com; Tel.: +20-2-3567-6608
}

Academic Editor: Panayiotis A. Koutentis

Received: 15 November 2016; Accepted: 14 February 2017; Published: 18 February 2017

\begin{abstract}
Novel 2-thiazolylphthalazine derivatives were efficiently synthesized under ultrasound irradiation, resulting in high yields and short reaction times after optimization of the reaction conditions. All prepared compounds were fully characterized using spectroscopic methods. They were screened for their antimicrobial activity against Gram-positive and Gram-negative bacteria as well as for antifungal activity. The antimicrobial activity profile of the tested compounds showed some promising results. The potent activity of compounds $4 \mathbf{d}, \mathbf{7 b}(117 \%$ zone inhibition) and $\mathbf{7 c}$ (105\% zone inhibition) against Salmonella sp., exceeding that of the reference drug Gentamycin is particularly noteworthy. In general, the newly synthesized thiazolylphthalazine derivatives showed higher antimicrobial activity against the tested Gram-negative bacteria than against Gram-positive bacteria and fungi.
\end{abstract}

Keywords: thiazolylphthalazinediones; hydrazonoyl chlorides; ultrasound irradiation; antimicrobial activity

\section{Introduction}

There are only two naturally occurring phthalazine derivatives, namely azamerone (I, Figure 1), which was isolated in 2006 from amarine-derived Streptomyces species [1], and 6-azidotetrazolo [5,1-a]phthalazine (II, Figure 1), which was isolated in 1985 from Gymnodiniumbreve, a toxic red-tide dinoflagellate [2]. Some phthalazine derivatives have been reported to possess anticonvulsant [3], antitumor [4-6], anti-inflammatory [7], and antidiabetic and vasorelaxant activities [8]. Phthalazines have also shown interesting vasodialatory and antihypertensive properties [9]. It is important to point out that phthalazine moiety is at the core of many commercial drugs. For example, zopolrestat (III, Figure 1) is a drug used to decrease blood glucose levels, while hydralazine (IV, Figure 1) and budralazine (V, Figure 1) display vasodilating effects.

One of the most pivotal contributions of phthalazine derivatives is their antimicrobial activity. According to the literature, the most common substitution pattern of the target phthalazine skeleton is 1-,2- and 4- on the diazine part of the bicyclic system [10-12]. One extensive study illustrated the remarkable antifungal activity of 4-substituted-2-methylphthalazines, which as a result could be considered good lead compounds [13]. 
<smiles>CC(=O)c1nncc2c1C(=O)C1=C(OC(C)(C)C(Cl)C1)C2(O)CC1C(C)(C)CCC(Cl)C1(C)C</smiles>

Azamerone (I)<smiles>Nc1nnn2c1-c1ccccc1-2</smiles>

(II)<smiles>O=C(O)Cc1nn(Cc2nc3cc(C(F)(F)F)ccc3s2)c(=O)c2ccccc12</smiles>

Zopolrestat (III)<smiles>NNc1nncc2ccccc12</smiles>

Hydralazine (IV)<smiles>CC(C)=CC(C)=NNc1nncc2ccccc12</smiles>

Budralazine (V)

Figure 1. Natural products and marketing drugs containing phthalazine moiety.

Moreover, the bicyclic phthalazine skeleton has been proven to display appreciable broad spectrum antimicrobial activity against Gram-positive and Gram-negative bacteria as well as fungi [14]. In a recent study [15], various phthalazine derivatives bearing aliphatic, aryl, and heteroaryl side chains at the $\mathrm{C} 2$ position of the phthalazine skeleton exhibited potent antimicrobial effects. In addition, some sugar-based phthalazine compounds also act as broad spectrum antimicrobial agents [15].

Another important heterocyclic ring is the thiazole ring, which is an interesting building block found in a range of natural products and part of many potent biologically active molecules such as vitamin B1, the epothilones, penicillins, myxothiazol and bleomycin (Figure 2).<smiles></smiles><smiles>[R]C1(CCCCC[C@@H](O)[C@@H](C)C(=O)C(C)(C)C(O)CC(=O)O[C@@H](C)/C(C)=C/c2csc(C)n2)O[C@@H]1C</smiles>

epothilones<smiles>[R]C(=O)N[C@@H]1C(=O)N2[C@@H](C(=O)O)C(C)(C)S[C@H]12</smiles>

penicillin<smiles>CO/C(=C/C(N)=O)[C@@H](C)/C=C/c1csc(-c2csc(C(C)/C=C/C=C/C(C)C)n2)n1</smiles>

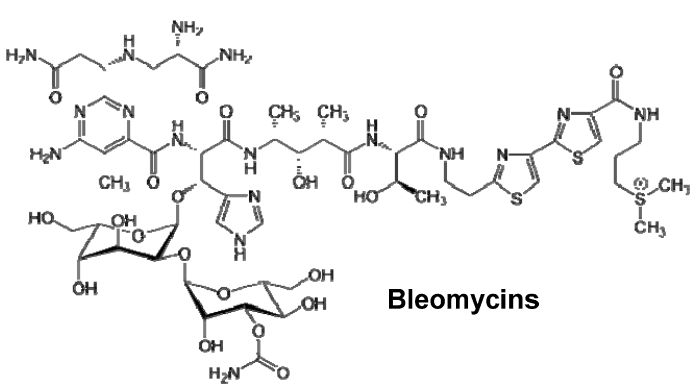

Figure 2. The structures of vitamin B1, the epothilones, penicillins, myxothiazol and bleomycin.

The value of the thiazolyl moiety as an antimicrobial agent has been reported in many studies. Some thiazolyl-based scaffolds with alkyl chains or aromatic rings at $\mathrm{C} 5$ also display potent antimicrobial activity [16].

Ultrasound-promoted synthesis has attracted much attention during the past few decades as a clean and useful procedure protocol in organic synthesis compared with traditional methods [17-19]. 
This is due to the method's cavitation process, which causes the formation, expansion, and collapse of a huge number of bubbles within short time, inducing rapid and violent implosions that create hot spots with very high local temperatures and pressures that which can be thought of as microreactors in which the sound energy is converted into a chemically useful form [17]. Considering the preceding reports, and in continuation of our work on the synthesis of bioactive compounds [20-26] and considering the worldwide antibiotic resistance crisis [27], we report herein our synthesis of a new series of thiazolylphthalazines using ultrasound irradiation with the aim of decreasing the reaction times and increasing the yields of the reaction products. In the synthesis described in this work we have adopted a molecular hybridization approach for the purpose of designing novel and more potent antimicrobial agents. To this end the target nuclei are hybrid thiazolyl scaffold-based phthalazine moieties, in which the phthalazine system is linked to different substituted thiazolyl nuclei at the $\mathrm{C} 2$ atom.

\section{Results and Discussion}

\subsection{Synthesis}

In continuation of our previous work on the synthesis of bioactive heterocyclic compounds under mild conditions [28-30], we report here simple and efficient procedures for the synthesis of some novel thiazolylphthalazinedione compounds via the reaction of 1,4-dioxo-3,4-dihydrophthalazine-2(1H)-carbothioamide (1) with different halogenated compounds under ultrasound irradiation. In order to optimize the reaction conditions, the reaction between compound $\mathbf{1}$ and hydrazonoyl chloride 2a was carried out using different solvents at two different temperatures (room temperature and $50^{\circ} \mathrm{C}$ ) under ultrasound irradiation (Table 1). In those experiments, we observed that the reactions were solvent dependent and, as shown in Table 1, the most suitable conditions involved ethanol as a solvent at $50^{\circ} \mathrm{C}$.

Table 1. Optimization of the synthesis of 2-(4-methyl-5-(phenyl-diazenyl)thiazol-2-yl)-2,3-dihydrophthalazine-1,4-dione (4a) under ultrasonic irradiation.

\begin{tabular}{ccccc}
\hline Entry & Solvent & Temperature $\left({ }^{\circ} \mathbf{C}\right)$ & Time $(\mathbf{m i n})$ & Yield (\%) \\
\hline 1 & EtOH & r.t. & 40 & 90 \\
2 & EtOH & 50 & 35 & 92 \\
3 & Dioxane & r.t. & 60 & 82 \\
4 & Dioxane & 50 & 45 & 87 \\
5 & DMF & r.t. & 40 & 85 \\
6 & DMF & 50 & 35 & 85 \\
7 & Benzene & r.t. & 45 & 89 \\
8 & Benzene & 50 & 40 & 91 \\
9 & Toluene & r.t. & 60 & 87 \\
10 & Toluene & 50 & 50 & 90 \\
\hline
\end{tabular}

In addition, we compare the efficiency of ultrasound conditions with conventional heating, considering there action yield and time. Table 2 shows that our method is simpler, more efficient, and less time consuming for the synthesis of thiazolylphthalazine derivatives.

The reaction between 1,4-dioxo-3,4-dihydrophthalazine-2 $(1 H)$-carbothioamide $(\mathbf{1})$ and acetyl hydrazonoyl chloride derivatives 2 in ethanol, in the presence of a base catalyst under optimized conditions, yielded only one isolated product (Scheme 1). The spectroscopic information confirmed the formation of products 4 , likely produced via intermediates 3 by elimination of a water molecule (Scheme 1). For example, the ${ }^{1} \mathrm{H}-\mathrm{NMR}$ spectra of compounds $4 \mathbf{a}-\mathbf{f}$, which exhibited singlet signals at $\delta$ 2.55-2.60 ppm $\left(\mathrm{CH}_{3}\right)$ and one $\mathrm{D}_{2} \mathrm{O}$ exchangeable peak at $\delta$ 9.18-10.71 ppm corresponding to the phthalazine-NH. 
Table 2. Comparison of synthesis of thiazolylphthalazines 4 and 7 under ultrasound irradiation and conventional heating.

\begin{tabular}{ccccc}
\hline \multirow{2}{*}{ Product No. } & \multicolumn{2}{c}{ Conventional } & \multicolumn{2}{c}{ Sonication } \\
\cline { 2 - 5 } & Time (h) & Yield (\%) & Time (min) & Yield (\%) \\
\hline 4a & 4 & 68 & 35 & 92 \\
4b & 4 & 69 & 50 & 84 \\
4c & 6 & 70 & 50 & 88 \\
4d & 4 & 71 & 40 & 86 \\
$4 \mathbf{4 e}$ & 4 & 74 & 55 & 88 \\
$\mathbf{4 f}$ & 3 & 67 & 45 & 87 \\
$7 \mathbf{a}$ & 6 & 65 & 60 & 85 \\
$7 \mathbf{b}$ & 5 & 67 & 40 & 83 \\
$7 \mathbf{c}$ & 5 & 68 & 50 & 85 \\
$7 \mathbf{d}$ & 4 & 69 & 55 & 83 \\
\hline
\end{tabular}<smiles>CC(=O)/C(Cl)=N/N[Ga]CC(C)C</smiles>

$\mathrm{Ar}=\mathrm{a}, \mathrm{Ph} ; \mathrm{b}, 4-\mathrm{MeC}_{6} \mathrm{H}_{4} ; \mathrm{c}, 2-\mathrm{MeC}_{6} \mathrm{H}_{4} ; \mathrm{d}, 4-\mathrm{MeOC}_{6} \mathrm{H}_{4}$;<smiles>Cc1nc(-n2[nH]c(=O)c3ccccc3c2=O)sc1/N=N/[Ba]</smiles>

Scheme 1. Synthesis of the thiazole derivatives 4 .

In an identical way, when carbothioamide 1 was allowed to react with the ethyl ( $N$-arylhydrazono)-chloroacetates $\mathbf{5}$ under the same reaction conditions, it yielded in each case a single product, namely, the 2-(4-oxo-5-(2-arylhydrazono)-4,5-dihydrothiazol-2-yl)-2,3-dihydrophthalazine1,4-dione $\mathbf{7}$ (Scheme 2). The structure of compounds $7 \mathbf{a}-\mathbf{d}$ was proved using spectral data and elemental analyses (see Section 3). The carbothioicacidamide 1 seemed to be useful synthon for the synthesis of different heterocyclic compounds. Thus, the reaction of compound $\mathbf{1}$ with halogenated ketones 8-11 afforded new thiazole derivatives 12-15 (Scheme 3). These reactions were carried out under ultrasound irradiation and gave excellent yield in short reaction times (Table 3). The structure of compounds 12-15 was determined using spectroscopic data. For example, the ${ }^{1} \mathrm{H}-\mathrm{NMR}$ spectrum of compound 15 showed the following signals: 7.37-8.65 (m, $8 \mathrm{H}, \mathrm{Ar}-\mathrm{H}), 8.36(\mathrm{~s}, 1 \mathrm{H}$, coumarine-H4), $8.64(\mathrm{~s}, 1 \mathrm{H}$, thiazole-H5), 8.87 (s, br, $1 \mathrm{H}, \mathrm{NH}, \mathrm{D}_{2} \mathrm{O}$-exchangeable). The mass spectrum of the thiazolylphthalazine derivative 13 revealed the existence of a molecular ion peak at $m / z=401$. Also, the infrared spectra of thiazoles 12-15 were free from any absorption bands characteristic of the $\mathrm{NH}_{2}$ group. 


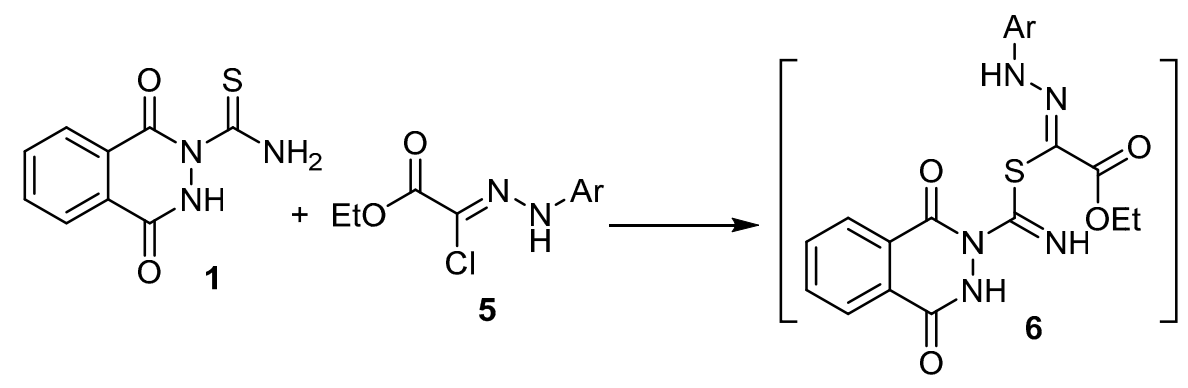

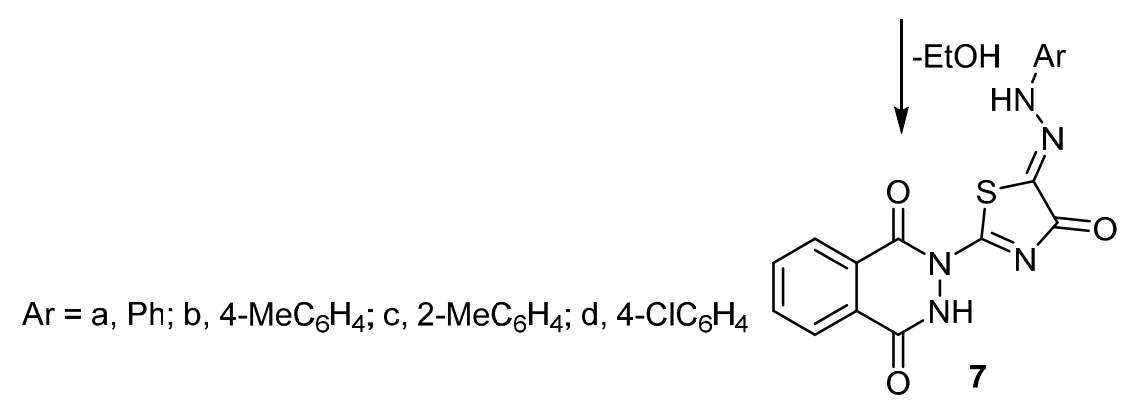

Scheme 2. Synthesis of thiazole derivatives 7.

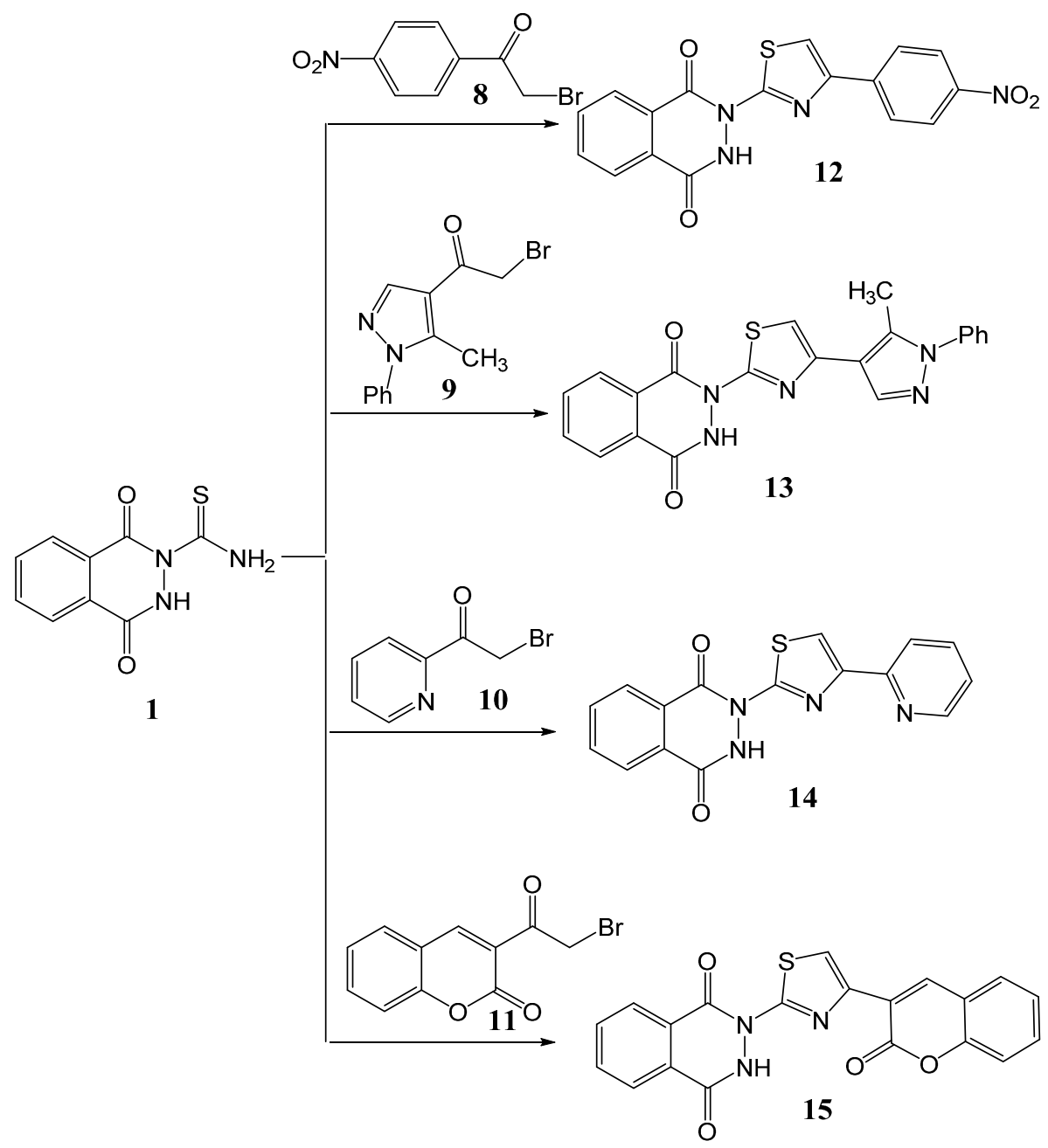

Scheme 3. Synthesis of the thiazole derivatives (12-15). 
From literature reports [31-33] we found that compounds bearing more than one thiazole ring unit also exhibit good biological activities. For example, myxothiazol (Figure 2) is an inhibitor of the mitochondrial cytochrome bc1 complex, and bleomycins is an anti-cancer agent, containing $2,4^{\prime}$-bis-thiazole system. From the above findings, we thought it is useful to synthesize a heterocyclic ring system carrying bis-thiazole moiety incorporated with a phthalazine ring. This aim was achieved via the reaction of bis-bromoketones $\mathbf{1 6}$ and $\mathbf{1 7}$ with the carbothioic acid amide $\mathbf{1}$, also under ultrasound irradiation to afford a good yield of the bis-thiazoles 18 and 19 (Scheme 4, Table 3). The structure of compounds 18 and 19 was proved using spectral data and elemental analyses (Section 3).

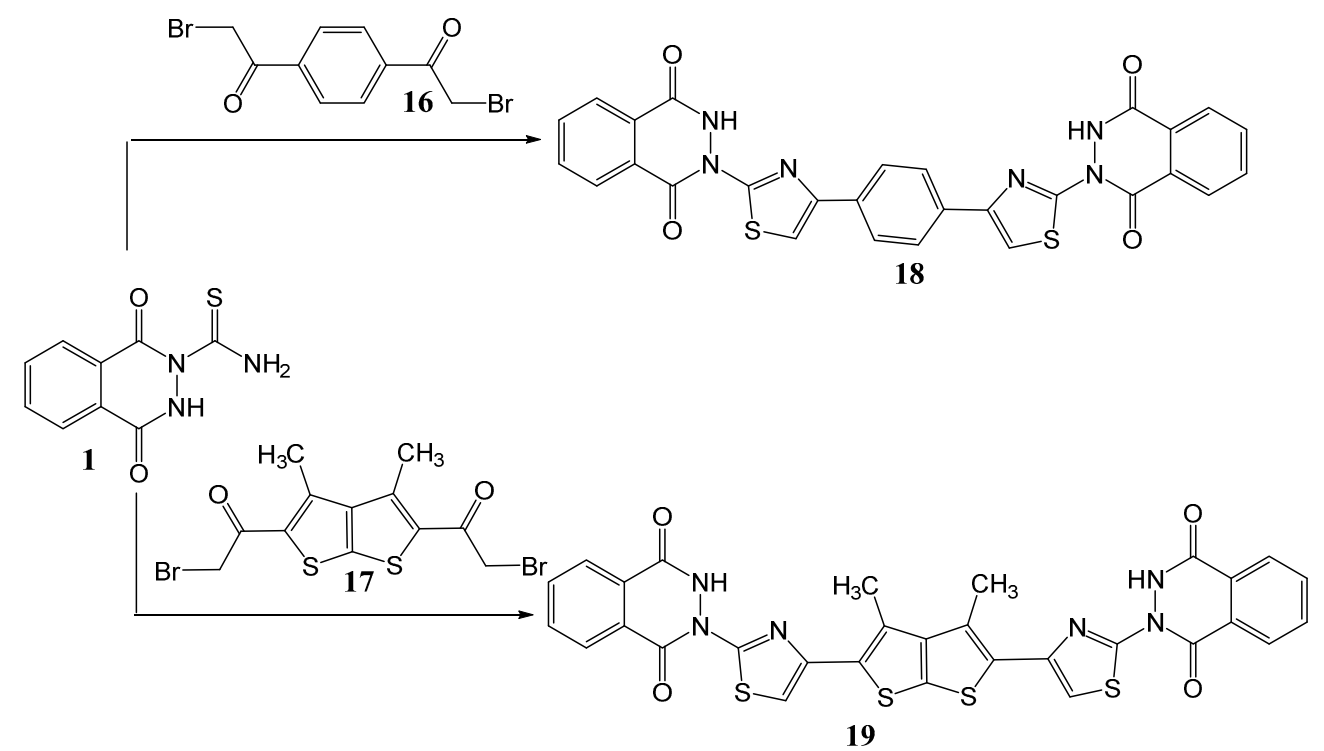

Scheme 4. Synthesis of the bis-thiazole derivatives 18 and 19.

Table 3. Comparison of synthesis of thiazolylphthalazines 12-15 and 18, 19 under ultrasound irradiation and conventional heating.

\begin{tabular}{ccccc}
\hline \multirow{2}{*}{ Product No. } & \multicolumn{2}{c}{ Conventional } & \multicolumn{2}{c}{ Sonication } \\
\cline { 2 - 5 } & Time (h) & Yield (\%) & Time (min) & Yield (\%) \\
\hline $\mathbf{1 2}$ & 5 & 70 & 35 & 84 \\
$\mathbf{1 3}$ & 4 & 67 & 50 & 82 \\
$\mathbf{1 4}$ & 4 & 72 & 60 & 88 \\
$\mathbf{1 5}$ & 6 & 69 & 40 & 84 \\
$\mathbf{1 8}$ & 5 & 70 & 55 & 85 \\
$\mathbf{1 9}$ & 7 & 68 & 45 & 83 \\
\hline
\end{tabular}

\subsection{Antimicrobial Activity}

The protocol of antimicrobial screening adopted an agar diffusion technique [34] at the Regional Center of Mycology and Biotechnology, Al-Azhar University, Cairo, Egypt. All synthesized compounds were screened for their antifungal and antibacterial activities (gram-positive and gram-negative) at concentrations of $5 \mathrm{mg} / \mathrm{mL}$. Amphotericine $B$, ampicillin and gentamycin were used as standard antifungal and antibacterial agents (gram-positive and gram-negative) respectively. The tested fungi were Aspergillus fumigates and Candida albicans. Tested gram-positive bacteria were Staphylococcus aureus and Bacillus subtilis, while gram-negative were Salmonella sp. and Escherichia coli. Susceptibilities of microbial isolates to the test compounds were recorded by measuring the average diameter of bacterial growth inhibition zones surrounding the well (in millimeters) compared to those surrounding the reference drugs. The obtained data indicated variable responses of cultured microorganisms towards 
the test compounds $\mathbf{1}, \mathbf{4 a}-\mathbf{f}, \mathbf{7 a}-\mathbf{d}, \mathbf{1 2}-\mathbf{1 5}, \mathbf{1 8}$, and 19. So, diverse inhibitory zones ranges (0 to $21 \mathrm{~mm})$ resulted, compared to the reference drugs. The inhibitory zone profile of the microbial isolates is shown in Table 4.

Table 4. Antimicrobial activity of the new compounds compared to reference drug.

\begin{tabular}{|c|c|c|c|c|c|c|}
\hline \multirow{3}{*}{ Compd. No. ${ }^{a}$} & \multicolumn{6}{|c|}{ Inhibition Zone Diameter in $\mathrm{mm}$ and (\%) Value } \\
\hline & \multicolumn{2}{|c|}{ Gram-Positive Bacteria } & \multicolumn{2}{|c|}{ Gram-Negative Bacteria } & \multicolumn{2}{|c|}{ Fungi } \\
\hline & SA & BS & S SP. & EC & AF & CA \\
\hline 1 & NA & $12(37 \%)$ & $16(94 \%)$ & NA & $8(34 \%)$ & $13(52 \%)$ \\
\hline $4 a$ & $8(34 \%)$ & $11(34 \%)$ & $15(88 \%)$ & $11(57 \%)$ & NA & $11(44 \%)$ \\
\hline $4 b$ & $16(69 \%)$ & $16(50 \%)$ & $15(88 \%)$ & $16(84 \%)$ & $10(43 \%)$ & NA \\
\hline $4 c$ & $11(47 \%)$ & $13(40 \%)$ & $14(82 \%)$ & $13(68 \%)$ & $12(52 \%)$ & $15(60 \%)$ \\
\hline $4 d$ & $10(43 \%)$ & $13(40 \%)$ & $20(117 \%)$ & $10(52 \%)$ & NA & $13(52 \%)$ \\
\hline $4 e$ & $12(52 \%)$ & NA & $9(52 \%)$ & NA & NA & $12(48 \%)$ \\
\hline $4 f$ & $14(60 \%)$ & $12(37 \%)$ & $15(88 \%)$ & 15 (78\%) & $12(52 \%)$ & $15(60 \%)$ \\
\hline $7 a$ & NA & $10(31 \%)$ & NA & NA & NA & $10(40 \%)$ \\
\hline $7 \mathbf{b}$ & NA & $9(28 \%)$ & $20(117 \%)$ & $9(47 \%)$ & $8(34 \%)$ & $12(48 \%)$ \\
\hline $7 c$ & NA & $12(37 \%)$ & $18(105 \%)$ & $10(52 \%)$ & $9(39 \%)$ & $14(56 \%)$ \\
\hline $7 d$ & NA & NA & NA & NA & NA & NA \\
\hline 12 & NA & $11(34 \%)$ & NA & NA & NA & $11(44 \%)$ \\
\hline 13 & NA & $12(37 \%)$ & NA & NA & NA & NA \\
\hline 14 & $12(52 \%)$ & NA & $12(70 \%)$ & $16(84 \%)$ & $14(60 \%)$ & NA \\
\hline 15 & $14(60 \%)$ & $12(37 \%)$ & $9(52 \%)$ & $9(47 \%)$ & $16(69 \%)$ & NA \\
\hline 18 & $15(65 \%)$ & $15(46 \%)$ & $15(88 \%)$ & $15(78 \%)$ & $15(65 \%)$ & $21(84 \%)$ \\
\hline 19 & $11(47 \%)$ & $11(34 \%)$ & $10(58 \%)$ & NA & $8(34 \%)$ & $15(60 \%)$ \\
\hline AmphotericinB & - & - & - & - & $23(100 \%)$ & $25(100 \%)$ \\
\hline Ampicillin & $23(100 \%)$ & $32(100 \%)$ & - & - & - & - \\
\hline Gentamycin & - & - & $17(100 \%)$ & $19(100 \%)$ & - & - \\
\hline
\end{tabular}

${ }^{\mathrm{a}}$ conc. $=5 \mathrm{mg} \cdot \mathrm{mL}^{-1}$, negative control (DMSO). NA (indicates no activity). Tested fungi: Aspergillus fumigates (AF) and Candida albicans (CA). Tested gram-positive bacteria: Staphylococcus aureus (SA) and Bacillus subtilis (BS). Tested gram-negative bacteria: Salmonella sp. (S SP.), Esherichia coli (EC). The experiment was carried out in triplicate and the values represent the average zone of inhibition.

\subsubsection{Antibacterial Activity}

The performance of the test compounds against Gram-positive S. aureus did not exceed that of the ampicillin used as a reference standard. Noticeably, compounds $\mathbf{4 b}$ and $\mathbf{1 8}$ exerted moderate activity (69\% and 65\% inhibition zones, respectively) compared to ampicillin. Compounds $4 \mathbf{f}$ and 15 exerted a 60\% inhibition zone ratio compared to ampicillin. On the other hand, 1, 7a-d, 12, and 13 were devoid of any activities against $S$. aureus. Bacillus subtilis exhibited higher resistance rates towards the test compounds. Compound $4 \mathbf{b}$ was the only one that exhibited a $50 \%$ inhibition zone ratio compared to ampicillin. The activity profile against Gram-negative bacteria indicated remarkable activity against Salmonella sp. Among the test compounds, four pthalazine derivatives exceeded the activity of gentamycin as a reference standard. Thus, the relative inhibition zone of $7 \mathrm{c}$ was $105 \%$ and those of $\mathbf{4 d}$ and $\mathbf{7 b}$ were $117 \%$, compared to that of gentamycin. Compounds $4 \mathbf{a}, \mathbf{4 b}, \mathbf{4 f}$, and 18 were equipotent, exerting high activity with an $88 \%$ inhibition zone ratio. The activities of $4 \mathrm{c}$ and 14 were appreciable, with $82 \%$ and $70 \%$ inhibition zone ratios, respectively (Table 4 ). However, the profiles against the second Gram-negative bacterium, Escherichia coli, were quite different. Escherichia coli cultures displayed a higher resistance rate than Salmonella sp. Only compounds $4 \mathbf{b}, 14$ (84\% inhibition zone each), and 18 (78\% inhibition zone) exerted high activity rates compared to gentamycin.

\subsubsection{Antifungal Activity}

The recorded data reflected weaker antifungal profiles for the test compounds $\mathbf{1 , 4 a - f , ~ 7 a - d , ~ 1 2 - 1 5 , ~}$ 18, and 19 than as antibacterial agents. Aspergillus fumigates exhibited a high resistance rate, as only 
compounds 14, 15, and 18 showed moderate activity ranging from 60\%-69\% inhibition zone ratios compared to Amphotericin B. On the other hand, compounds 1,4b, 4c, 4f, 7b, 7c, and 19 exhibited mild-to-weak activity, showing an inhibition zone percentage range of $34 \%-52 \%$. The rest of the test compounds were in active.

In contrast, Candida albicans showed greater sensitivity toward compound 18, which exhibited high antifungal activity with an $84 \%$ inhibition zone rate compared to Amphotericin B. Compounds 4c, 4f, and 19 showed moderate activity with a 60\% inhibition zone, while others showed poor-to-negative effects. In conclusion, the antimicrobial profile of the test compound included some promising results. Noticeably, compound 18 demonstrated abroad antimicrobial spectrum. It exhibited high antibacterial activity against Salmonella sp. (88\% potency), with concomitant good antifungal activity against Candida albicans (84\% potency). Also, it exerted moderate activities against Escherichia coli $(78 \%$ potency) and S. aureus (65\% potency). Compound $4 \mathbf{b}$ was potent against Salmonella sp. (88\% potency) with concomitant good activity against Escherichia coli (84\% potency) and moderate activity against $S$. aureus (69\% potency). In particular, the remarkable activity of 4 f against Salmonella $s p$. (88\% potency) could not be ignored. An interesting issue is the potent activity of $\mathbf{4 d}, \mathbf{7 b}$ (117\% zone inhibition), and 7c (105\% zone inhibition) against Salmonella sp., exceeding that of the reference drug gentamycin. Generally, the profiles of the newly synthesized thiazolylphthalazine derivatives exhibited higher antimicrobial activity against the tested Gram-negative bacteria than Gram-positive ones andfungi.Thetestcompoundsshouldbesubjectedtofurtherinvestigationto identify selective lead compounds.

\subsubsection{Structure-Activity Relationships (SAR)}

Adopting the hybridization approach, a new series of novel thiazolylphthalazine hybrids was synthesized. The test compounds are mapped into four structure profiles: A (4a-f), B (7a-d), C $\mathbf{( 1 2 - 1 5 )}$, and D $(\mathbf{1 8 , 1 9 )}$ employing phthalazinecarbothioamide 1 as a starting precursor (Figure 3 ). The successful synthesis of effective antimicrobial agents was demonstrated by the significant effects against gram-negative bacteria (Salmonella sp.) seen in the screening. The recorded data confirmed compounds $\mathbf{4 b}, \mathbf{4 d}$, and $\mathbf{4 f}$ as the most potent derivatives in group A against Salmonella sp. compared to gentamycin. Precursor 1 exerted high antimicrobial activity (94\% inhibition zone) that increased remarkably to a $117 \%$ inhibition zone in compound $4 \mathbf{d}$. This result was resulted after incorporating the non-cyclic thiamido group in $\mathbf{1}$ in to the heterocyclic thiazolyl moiety in $\mathbf{4 d}$. Also, the SAR study illustrated the positive effect of a $p$-methoxyphenyl group linked to the diazine moiety at $\mathrm{C} 5$ of the thiazole ring. On the other hand, $\mathbf{4 a}, \mathbf{4 b}$, and $\mathbf{4 f}$ possess similar structures, differing in the substitution the $p-\mathrm{OCH}_{3}$ moiety by a $p-\mathrm{H}, p-\mathrm{CH}_{3}$ or $p-\mathrm{NO}_{2}$, respectively, which each resulted in $88 \%$ activity, so the SAR comparison demonstrated that incorporation of a hydrophilic electron-donating group in the para position, for example the $p-\mathrm{OCH}_{3}$ group in $4 \mathrm{~d}$, greatly increased the antimicrobial activity. Also, switching from $p-\mathrm{CH}_{3}$ in $4 \mathrm{~b}$ to $o-\mathrm{CH}_{3}$ in $4 \mathrm{c}$ slightly decreased the inhibition zone activity from $88 \%$ to $82 \%$. Finally, the existence of a $p$-chloro group in $4 \mathbf{e}$ abruptly decreased activity against Salmonella $s p$. To an inhibition zone of only 52\%. Regarding the second group, B (compounds 7a-d), Gram-negative bacteria, for example Salmonella sp., were the most sensitive organisms to this group. Compounds $7 \mathbf{b}$ and $7 \mathrm{c}$ exerted potent activity, with $117 \%$ and 105\% inhibition zones, respectively. Their structural profiles included a hydrazone moiety as a linker. Noticeably, when the $p-\mathrm{CH}_{3}$ group in $7 \mathbf{b}$ was switched to $o-\mathrm{CH}_{3}$ in $\mathbf{7 c}$, a concomitant slight decrease in activity was noted. Similarly, switching the $\mathrm{CH}_{3}$ moiety in group $A$ between $\mathbf{4 b}$ and $\mathbf{4 c}$ slightly affected their activity.

Thus, it seemed that the steric effect of the phenyl group in $\mathbf{4 b , c}$, and $\mathbf{7 b}, \mathbf{c}$ did not play agreat role in the antimicrobial activity against Salmonella sp. Again, $p$-chlorosubstitution in $\mathbf{7 d}$ completely abolished the activity and the plain phenyl group in 8a as good. Group C (compounds 12-15) proved the vital role of either diazine or hydrazone linkers. Noticeably, direct linking between the thiazolylpthalazine hybrid and the aryl/heteroaryl moieties exerted a negative impact on the antimicrobial activity. Compound 15 in group $C$ showed a slight improvement of activity, which could be attributed to the 
existence of the coumarin nucleus [35]. Further, the bimolecular system in group D (compounds 18 and 19) possesses appreciable antimicrobial activity. Compound 18, bearing a phenyl group linker between the bimolecular thiazolylphthalazine hybrids, exhibited better activity. It selectively inhibited the growth of Candida albicans and Salmonella sp. (84\% and $88 \%$ inhibition zones, respectively). Among the four groups, 18 was the only compound that showed high antifungal activity against Candida albicans.

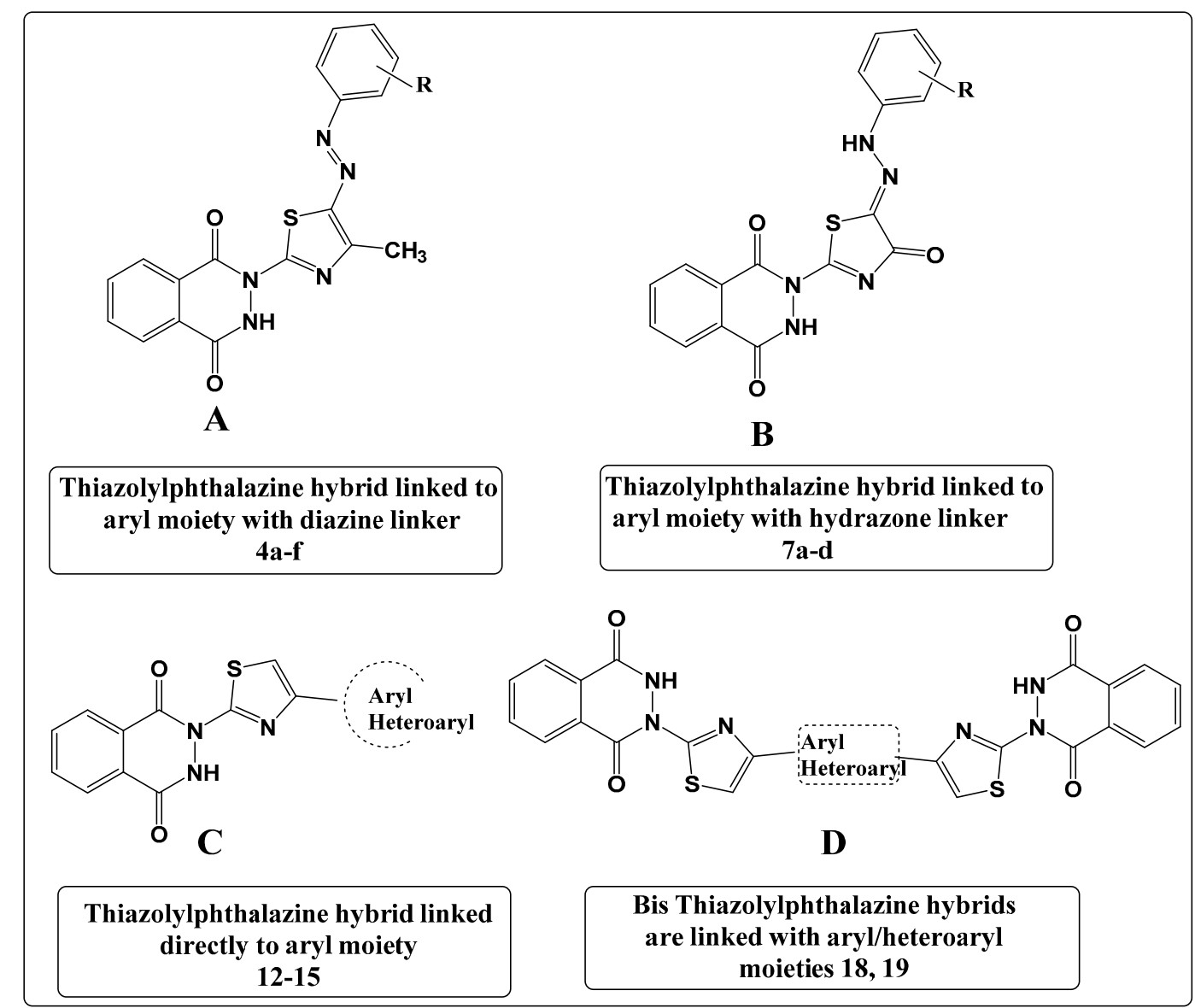

Figure 3. Structural profile map of the test compounds.

\section{Materials and Methods}

\subsection{General Experimental Procedures}

Melting points were measured with an IA 9000-series digital melting-point apparatus (Bibby Sci. Lim. Stone, Staffordshire, UK). IR spectra were recorded in potassium bromide discs on FTIR 8101 PC infrared spectrophotometers (Shimadzu, Tokyo, Japan). NMR spectra were recorded on a Mercury VX-300 NMR spectrometer (Varian, Inc., Karlsruhe, Germany) operating at $300 \mathrm{MHz}$ $\left({ }^{1} \mathrm{H}-\mathrm{NMR}\right)$ and run in deuterated dimethylsulfoxide (DMSO- $\left.d_{6}\right)$. Chemical shifts were related to that of the solvent. Mass spectra were recorded on a Shimadzu GCeMS-QP1000 EX mass spectrometer (Tokyo, Japan) at $70 \mathrm{eV}$. Elemental analyses were measured using an ElementarVario LIII CHNS analyzer (elementar Analysensysteme $\mathrm{GmbH}$, Hanau, Germany). Ultrasonication was carried out in an ElmaRD-7700 apparatus (Singen, Germany). The electric supply was 230 V, A.C. 50 Hz, 1 phase; the ultrasonic frequency was $36 \mathrm{KHz}$ and the ultrasonic power $100 \mathrm{~W}$. 1,4-Dioxo-3,4-dihydrophthalazine2(1H)-carbothioamide (1) [36] and hydrazonoyl halides 2 and 5 [37] were prepared as previously reported in the respective literature. 


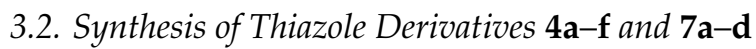

\subsubsection{Method A}

A mixture of 1,4-dioxo-3,4-dihydrophthalazine-2(1H)-carbothioamide $(\mathbf{1}, 0.221 \mathrm{~g}, 1 \mathrm{mmol})$ and the appropriate hydrazonoyl halides $\mathbf{2} \mathbf{a}-\mathbf{f}$ or $\mathbf{5 a}-\mathbf{d}(1 \mathrm{mmol})$ in ethanol $(20 \mathrm{~mL})$ containing triethylamine $(0.1 \mathrm{~g}, 1 \mathrm{mmol})$ was refluxed for 3-6 h (monitored by TLC). The formed precipitate was isolated by filtration, washed with methanol, dried, and recrystallized from the appropriate solvent to give products $4 \mathbf{a}-\mathbf{f}$ and $7 \mathbf{a}-\mathbf{d}$, respectively. The physical properties and spectral data of the obtained products are listed below.

\subsubsection{Method B}

To a mixture of equimolar amounts of compound $1(0.221 \mathrm{~g}, 1 \mathrm{mmol})$ and the appropriate hydrazonoyl halides $\mathbf{2 a}-\mathbf{f}$ or $\mathbf{5 a}-\mathbf{d}(1 \mathrm{mmol})$ in ethanol $(20 \mathrm{~mL})$, was added TEA $(0.1 \mathrm{~g})$. The reaction mixture was irradiated by an ultrasonic generator in a water bath at $50{ }^{\circ} \mathrm{C}$ for $30-60$ min (irradiation was continued till all of the starting materials had disappeared and the product was formed, as monitored by TLC). The solid that formed after cooling was filtered and recrystallized from appropriate solvent to give compounds $4 \mathbf{a}-\mathbf{f}$ and $7 \mathbf{a}-\mathbf{d}$, respectively.

2-(4-Methyl-5-(phenyldiazenyl)thiazol-2-yl)-2,3-dihydrophthalazine-1,4-dione (4a). Red solid; m.p. $213-215^{\circ} \mathrm{C}$ (Dioxane); IR (KBr): $v 3411(\mathrm{NH}), 3049,2931(\mathrm{C}-\mathrm{H}), 1668,1654(2 \mathrm{C}=\mathrm{O}), 1598(\mathrm{C}=\mathrm{N}) \mathrm{cm}^{-1} ;{ }^{1} \mathrm{H}-\mathrm{NMR}$ $\left(\mathrm{DMSO}-d_{6}\right): \delta 2.55\left(\mathrm{~s}, 3 \mathrm{H}, \mathrm{CH}_{3}\right), 7.02-7.91(\mathrm{~m}, 9 \mathrm{H}, \mathrm{Ar}-\mathrm{H}), 10.42$ (s, br, 1H, NH, D2O-exchangeable); ${ }^{13}$ C-NMR (DMSO- $d_{6}$ ): $\delta$ 16.1, 106.1, 114.3, 115.5, 115.7, 126.4, 128.4, 129.6, 132.5, 146.2, 155.8, 155.9, 160.2, 162.0, 162.5, 165.0. MS m/z (\%): $363\left(\mathrm{M}^{+}\right)$. Anal. Calcd. for $\mathrm{C}_{18} \mathrm{H}_{13} \mathrm{~N}_{5} \mathrm{O}_{2} \mathrm{~S}$ (363.08): C, 59.49; $\mathrm{H}$, 3.61; N, 19.27. Found: C, 59.42; H, 3.58; N, 19.14\%.

2-(4-Methyl-5-(p-tolyldiazenyl)thiazol-2-yl)-2,3-dihydrophthalazine-1,4-dione (4b). Red solid; m.p. $187-189{ }^{\circ} \mathrm{C}$ (EtOH); IR (KBr): $v 3423(\mathrm{NH}), 3027,2918(\mathrm{C}-\mathrm{H}), 1670,1654(2 \mathrm{C}=\mathrm{O}), 1603(\mathrm{C}=\mathrm{N}) \mathrm{cm}^{-1} ;{ }^{1} \mathrm{H}-\mathrm{NMR}$ $\left(\mathrm{DMSO}-d_{6}\right): \delta 2.27\left(\mathrm{~s}, 3 \mathrm{H}, \mathrm{CH}_{3}\right), 2.57\left(\mathrm{~s}, 3 \mathrm{H}, \mathrm{CH}_{3}\right), 7.10-8.06(\mathrm{~m}, 8 \mathrm{H}, \mathrm{Ar}-\mathrm{H}), 9.18(\mathrm{~s}, \mathrm{br}, 1 \mathrm{H}, \mathrm{NH}$, $\mathrm{D}_{2} \mathrm{O}$-exchangeable); $\mathrm{MS} m / z(\%): 377\left(\mathrm{M}^{+}\right)$. Anal. Calcd. for $\mathrm{C}_{19} \mathrm{H}_{15} \mathrm{~N}_{5} \mathrm{O}_{2} \mathrm{~S}$ (377.09): $\mathrm{C}, 60.46 ; \mathrm{H}, 4.01$; N, 18.56. Found: C, 60.39; H, 4.07; N, 18.44\%.

2-(4-Methyl-5-(o-tolyldiazenyl)thiazol-2-yl)-2,3-dihydrophthalazine-1,4-dione (4c). Red solid; m.p. 206-208 ${ }^{\circ} \mathrm{C}$ $(\mathrm{EtOH})$; IR (KBr): $v 3426(\mathrm{NH}), 3031,2921(\mathrm{C}-\mathrm{H}), 1667,1559(2 \mathrm{C}=\mathrm{O}), 1590(\mathrm{C}=\mathrm{N}) \mathrm{cm}^{-1} ;{ }^{1} \mathrm{H}-\mathrm{NMR}$ $\left(\mathrm{DMSO}_{6}\right): \delta 2.32\left(\mathrm{~s}, 3 \mathrm{H}, \mathrm{CH}_{3}\right), 2.60\left(\mathrm{~s}, 3 \mathrm{H}, \mathrm{CH}_{3}\right), 7.18-7.94(\mathrm{~m}, 8 \mathrm{H}, \mathrm{Ar}-\mathrm{H}), 10.47(\mathrm{~s}, \mathrm{br}, 1 \mathrm{H}, \mathrm{NH}$, $\mathrm{D}_{2} \mathrm{O}$-exchangeable); $\mathrm{MS} m / z(\%): 377\left(\mathrm{M}^{+}\right)$. Anal. Calcd. for $\mathrm{C}_{19} \mathrm{H}_{15} \mathrm{~N}_{5} \mathrm{O}_{2} \mathrm{~S}$ (377.09): C, 60.46; $\mathrm{H}, 4.01$; N, 18.56. Found: C, 60.42; H, 4.00; N, 18.47\%.

2-(5-((4-Methoxyphenyl)diazenyl)-4-methylthiazol-2-yl)-2,3-dihydrophthalazine-1,4-dione (4d). Red solid; m.p. 177-178 ${ }^{\circ} \mathrm{C}(\mathrm{EtOH})$; IR (KBr): $v 3429(\mathrm{NH}), 3029,2922(\mathrm{C}-\mathrm{H}), 1683,1650(2 \mathrm{C}=\mathrm{O}), 1598(\mathrm{C}=\mathrm{N}) \mathrm{cm}^{-1}$; ${ }^{1} \mathrm{H}-\mathrm{NMR}\left(\mathrm{DMSO}-d_{6}\right): \delta 2.57\left(\mathrm{~s}, 3 \mathrm{H}, \mathrm{CH}_{3}\right), 3.80\left(\mathrm{~s}, 3 \mathrm{H}, \mathrm{OCH}_{3}\right), 6.93-8.05(\mathrm{~m}, 8 \mathrm{H}, \mathrm{Ar}-\mathrm{H}), 10.27(\mathrm{~s}, \mathrm{br}, 1 \mathrm{H}$, $\mathrm{NH}, \mathrm{D}_{2} \mathrm{O}$-exchangeable); $\mathrm{MS} m / z(\%): 393\left(\mathrm{M}^{+}\right)$. Anal. Calcd. for $\mathrm{C}_{19} \mathrm{H}_{15} \mathrm{~N}_{5} \mathrm{O}_{3} \mathrm{~S}(393.09): \mathrm{C}, 58.01 ; \mathrm{H}$, 3.84; N, 17.80. Found: C, 57.87; H, 3.75; N, 17.69\%.

2-(5-((4-Chlorophenyl)diazenyl)-4-methylthiazol-2-yl)-2,3-dihydrophthalazine-1,4-dione (4e). Red solid; m.p. 237-239 ${ }^{\circ} \mathrm{C}(\mathrm{DMF}) ; \mathrm{IR}(\mathrm{KBr}): v 3423$ (NH), 3042, 2924 (C-H), 1671, $1640(2 \mathrm{C}=\mathrm{O}), 1591$ (C=N) cm ${ }^{-1},{ }^{1} \mathrm{H}-\mathrm{NMR}$ $\left(\mathrm{DMSO}_{-} \mathrm{d}_{6}\right): \delta 2.58\left(\mathrm{~s}, 3 \mathrm{H}, \mathrm{CH}_{3}\right), 7.23-7.89(\mathrm{~m}, 8 \mathrm{H}, \mathrm{Ar}-\mathrm{H}), 10.04$ (s, br, 1H, NH, D $\mathrm{O}-$ exchangeable); MS $m / z(\%): 397\left(\mathrm{M}^{+}\right)$. Anal. Calcd. for $\mathrm{C}_{18} \mathrm{H}_{12} \mathrm{ClN}_{5} \mathrm{O}_{2} \mathrm{~S}$ (397.04): C, 54.34; H, 3.04; N, 17.60. Found: C, $54.24 ; \mathrm{H}, 3.05 ; \mathrm{N}, 17.47 \%$.

2-(4-Methyl-5-((4-nitrophenyl)diazenyl)thiazol-2-yl)-2,3-dihydrophthalazine-1,4-dione (4f). Red solid; m.p. 225-227 ${ }^{\circ} \mathrm{C}(\mathrm{DMF}) ; \mathrm{IR}(\mathrm{KBr}): v 3425$ (NH), 3042, 2925 (C-H), 1673, $1655(2 \mathrm{C}=\mathrm{O}), 1594(\mathrm{C}=\mathrm{N}) \mathrm{cm}^{-1},{ }^{1} \mathrm{H}-\mathrm{NMR}$ $\left(\mathrm{DMSO}_{6}\right): \delta 2.57\left(\mathrm{~s}, 3 \mathrm{H}, \mathrm{CH}_{3}\right), 7.38-8.20(\mathrm{~m}, 8 \mathrm{H}, \mathrm{Ar}-\mathrm{H}), 10.71$ (s, br, 1H, NH, D 2 O-exchangeable); MS 
$m / z(\%): 408\left(\mathrm{M}^{+}\right)$. Anal. Calcd. for $\mathrm{C}_{18} \mathrm{H}_{12} \mathrm{~N}_{6} \mathrm{O}_{4} \mathrm{~S}$ (408.06): C, 52.94; $\mathrm{H}, 2.96 ; \mathrm{N}, 20.58$. Found: $\mathrm{C}, 52.80$; $\mathrm{H}, 2.90 ; \mathrm{N}, 20.49 \%$.

2-(4-Oxo-5-(2-phenylhydrazono)-4,5-dihydrothiazol-2-yl)-2,3-dihydrophthalazine-1,4-dione (7a). Yellow solid; m.p. $168-170{ }^{\circ} \mathrm{C}(\mathrm{EtOH})$; IR (KBr): $v$ 3371, $3178(2 \mathrm{NH}), 3051,2978(\mathrm{C}-\mathrm{H}), 1705,1644,1621$ (3C=O), $1600(\mathrm{C}=\mathrm{N}) \mathrm{cm}^{-1} ;{ }^{1} \mathrm{H}-\mathrm{NMR}$ (DMSO- $\left.d_{6}\right): \delta 6.94-7.96(\mathrm{~m}, 9 \mathrm{H}, \mathrm{Ar}-\mathrm{H}), 8.63,10.64(2 \mathrm{~s}, \mathrm{br}, 2 \mathrm{H}, 2 \mathrm{NH}$, $\mathrm{D}_{2} \mathrm{O}$-exchangeable); ${ }^{13} \mathrm{C}$-NMR (DMSO- $d_{6}$ ): $\delta 121.5,126.8,128.8,129.3,130.5,132.1,136.4,138.1,143.3$, 147.4, 149.2, 151.5, 162.2, 164.7, 188.1. MS $m / z(\%): 365\left(\mathrm{M}^{+}\right)$. Anal. Calcd. for $\mathrm{C}_{17} \mathrm{H}_{11} \mathrm{~N}_{5} \mathrm{O}_{3} \mathrm{~S}(365.06)$ : C, 55.88; H, 3.03; N, 19.17. Found: C, 55.73; H, 3.02; N, 19.11\%.

2-(4-Oxo-5-(2-(p-tolyl)hydrazono)-4,5-dihydrothiazol-2-yl)-2,3-dihydrophthalazine-1,4-dione (7b). Yellow solid; m.p. 179-181 ${ }^{\circ} \mathrm{C}(\mathrm{EtOH})$; IR (KBr): v 3426, 3178 (2NH), 3030, $2922(\mathrm{C}-\mathrm{H}), 1703,1649,1632$ (3C=O), $1601(\mathrm{C}=\mathrm{N}) \mathrm{cm}^{-1} ;{ }^{1} \mathrm{H}-\mathrm{NMR}$ (DMSO- $\left.d_{6}\right): \delta 2.26\left(\mathrm{~s}, 3 \mathrm{H}, \mathrm{CH}_{3}\right), 6.99-7.97(\mathrm{~m}, 8 \mathrm{H}, \mathrm{Ar}-\mathrm{H}), 10.54,10.79(2 \mathrm{~s}, \mathrm{br}$, $2 \mathrm{H}, 2 \mathrm{NH}, \mathrm{D}_{2} \mathrm{O}$-exchangeable); $\mathrm{MS} \mathrm{m} / z(\%): 379\left(\mathrm{M}^{+}\right)$. Anal. Calcd. for $\mathrm{C}_{18} \mathrm{H}_{13} \mathrm{~N}_{5} \mathrm{O}_{3} \mathrm{~S}$ (379.07): C, 56.98; H, 3.45; N,18.46. Found: C, 56.75; H, 3.40; N, 18.36\%.

2-(4-Oxo-5-(2-(o-tolyl)hydrazono)-4,5-dihydrothiazol-2-yl)-2,3-dihydrophthalazine-1,4-dione (7c). Yellow solid; m.p. 157-159 ㄷ (EtOH); IR (KBr): v 3428, 3179 (NH), 3049, 2925 (C-H), 1738, 1650, 1627 (3C=O), $1598(\mathrm{C}=\mathrm{N}) \mathrm{cm}^{-1} ;{ }^{1} \mathrm{H}-\mathrm{NMR}\left(\mathrm{DMSO}-d_{6}\right): \delta 2.17\left(\mathrm{~s}, 3 \mathrm{H}, \mathrm{CH}_{3}\right), 6.97-7.93(\mathrm{~m}, 8 \mathrm{H}, \mathrm{Ar}-\mathrm{H}), 9.93,10.25(2 \mathrm{~s}, \mathrm{br}$, $2 \mathrm{H}, 2 \mathrm{NH}, \mathrm{D}_{2} \mathrm{O}$-exchangeable); $\mathrm{MS} m / z(\%): 379\left(\mathrm{M}^{+}\right)$. Anal. Calcd. for $\mathrm{C}_{18} \mathrm{H}_{13} \mathrm{~N}_{5} \mathrm{O}_{3} \mathrm{~S}$ (379.07): C, 56.98; H, 3.45; N, 18.46. Found: C, 56.84; H, 3.40; N, 18.35\%.

2-(5-(2-(4-Chlorophenyl)hydrazono)-4-oxo-4,5-dihydrothiazol-2-yl)-2,3-dihydrophthalazine-1,4-dione (7d). Yellow solid; m.p. $185-187^{\circ} \mathrm{C}$ (EtOH/DMF); IR (KBr): $v$ 3429, $3183(\mathrm{NH}), 3054,2926(\mathrm{C}-\mathrm{H}), 1735,1657$, 1629 (3C=O), $1599(\mathrm{C}=\mathrm{N}) \mathrm{cm}^{-1},{ }^{1} \mathrm{H}-\mathrm{NMR}\left(\mathrm{DMSO}_{6}\right): \delta$ 7.33-7.97 (m, 8H, Ar-H), 10.27, 10.83 (2s, br, $2 \mathrm{H}, 2 \mathrm{NH}, \mathrm{D}_{2} \mathrm{O}$-exchangeable); $\mathrm{MS} m / z(\%): 399\left(\mathrm{M}^{+}\right)$. Anal. Calcd. For $\mathrm{C}_{17} \mathrm{H}_{10} \mathrm{ClN}_{5} \mathrm{O}_{3} \mathrm{~S}$ (399.02): $\mathrm{C}$, 51.07; $\mathrm{H}, 2.52 ; \mathrm{N}, 17.52$. Found: $\mathrm{C}, 51.01 ; \mathrm{H}, 2.39 ; \mathrm{N}, 17.42 \%$.

\subsection{Synthesis of Thiazole Derivatives $\mathbf{1 2 - 1 5}$}

\subsubsection{Method A}

A mixture of 1,4-dioxo-3,4-dihydrophthalazine-2(1H)-carbothioamide $(\mathbf{1}, 0.221 \mathrm{~g}, 1 \mathrm{mmol})$ and $\alpha$-bromoketones 8-11 $(1 \mathrm{mmol})$ in ethanol $(20 \mathrm{~mL})$ was refluxed for $4-6 \mathrm{~h}$ (monitored by TLC). The product started to separate out during the course of reaction. The solid product was filtered, washed with water, dried and recrystallized from appropriate solvent to give the corresponding thiazoles $12-15$, respectively.

\subsubsection{Method B}

A equimolar mixture of compound $\mathbf{1}(0.221 \mathrm{~g}, 1 \mathrm{mmol})$ and the appropriate and $\alpha$-bromoketones 8-11 (1 mmol) in ethanol $(20 \mathrm{~mL})$ was irradiated by an ultrasonic generator in a water bath at $50{ }^{\circ} \mathrm{C}$ for 30-60 min (irradiation was continued until all of the starting materials disappeared and the product was formed, as monitored by TLC). The solid that formed after cooling was filtered and recrystallized from an appropriate solvent to give the corresponding thiazoles 12-15, respectively.

2-(4-(4-Nitrophenyl)thiazol-2-yl)-2,3-dihydrophthalazine-1,4-dione (12). Yellow solid; m.p. $193-195{ }^{\circ} \mathrm{C}$ (EtOH); IR (KBr): $v 3430(\mathrm{NH})$, 3047, $2922(\mathrm{C}-\mathrm{H}), 1658,1643(2 \mathrm{C}=\mathrm{O}), 1597(\mathrm{C}=\mathrm{N}) \mathrm{cm}^{-1} ;{ }^{1} \mathrm{H}-\mathrm{NMR}$ (DMSO- $\left.d_{6}\right): \delta 6.98-8.38\left(\mathrm{~m}, 9 \mathrm{H}, \mathrm{Ar}-\mathrm{H}\right.$ and thiazole-H5), 8.81 (s, br, $1 \mathrm{H}, \mathrm{NH}, \mathrm{D}_{2} \mathrm{O}-$ exchangeable); ${ }^{13} \mathrm{C}-\mathrm{NMR}\left(\mathrm{DMSO}-d_{6}\right): \delta 112.4,116.1,125.8,127.9,129.3,129.6,130.3,133.0,134.7,138.5,145.3,148.4$, 149.9, 160.6, 163.0. MS $m / z$ (\%): $366\left(\mathrm{M}^{+}\right)$. Anal. Calcd. for $\mathrm{C}_{17} \mathrm{H}_{10} \mathrm{~N}_{4} \mathrm{O}_{4} \mathrm{~S}(366.04)$ : C, 55.73; $\mathrm{H}, 2.75 ; \mathrm{N}$, 15.29. Found: C, 55.59; $\mathrm{H}, 2.72 ; \mathrm{N}, 15.15 \%$.

2-(4-(5-Methyl-1-phenyl-1H-pyrazol-4-yl)thiazol-2-yl)-2,3-dihydrophthalazine-1,4-dione (13). Yellow solid; m.p. 230-232 ${ }^{\circ} \mathrm{C}$ (dioxane); IR (KBr): $v 3425(\mathrm{NH})$, 3040, $2925(\mathrm{C}-\mathrm{H}), 1673,1649(2 \mathrm{C}=\mathrm{O}), 1596(\mathrm{C}=\mathrm{N})$ $\mathrm{cm}^{-1} ;{ }^{1} \mathrm{H}-\mathrm{NMR}\left(\mathrm{DMSO}-d_{6}\right): \delta 2.59\left(\mathrm{~s}, 3 \mathrm{H}, \mathrm{CH}_{3}\right), 7.46-7.62(\mathrm{~m}, 6 \mathrm{H}, \mathrm{Ar}-\mathrm{H}$ and thiazole-H5), $7.78(\mathrm{~s}, 1 \mathrm{H}$, 
pyrazole-H3), 7.91-8.15 (m, 4H, Ar-H), 9.88 (s, br, 1H, NH, $\mathrm{D}_{2} \mathrm{O}-$-exchangeable); $\mathrm{MS} m / z(\%): 401\left(\mathrm{M}^{+}\right)$. Anal. Calcd. For $\mathrm{C}_{21} \mathrm{H}_{15} \mathrm{~N}_{5} \mathrm{O}_{2} \mathrm{~S}$ (401.09): $\mathrm{C}, 62.83 ; \mathrm{H}, 3.77 ; \mathrm{N}, 17.45$. Found: $\mathrm{C}, 62.77 ; \mathrm{H}, 3.64 ; \mathrm{N}, 17.38 \%$. 2-(4-(Pyridin-2-yl)thiazol-2-yl)-2,3-dihydrophthalazine-1,4-dione (14). Yellow solid; m.p. 200-202 ${ }^{\circ} \mathrm{C}$ $(\mathrm{EtOH}) ; \mathrm{IR}(\mathrm{KBr}): v 3427(\mathrm{NH}), 3048,2924(\mathrm{C}-\mathrm{H}), 1666,1643(2 \mathrm{C}=\mathrm{O}), 1589(\mathrm{C}=\mathrm{N}) \mathrm{cm}^{-1} ;{ }^{1} \mathrm{H}-\mathrm{NMR}$ (DMSO- $\left.d_{6}\right): \delta 7.23-8.65(\mathrm{~m}, 9 \mathrm{H}, \mathrm{Ar}-\mathrm{H}), 8.90\left(\mathrm{~s}, \mathrm{br}, 1 \mathrm{H}, \mathrm{NH}, \mathrm{D}_{2} \mathrm{O}-\right.$ exchangeable); ${ }^{13} \mathrm{C}-\mathrm{NMR}$ (DMSO- $d_{6}$ ): $\delta 106.5,115.5,115.7,125.2,126.2,126.3,129.8,131.9,132.6,135.2,146.6,155.7,156.1,159.4,162.6,165.1$. MS $m / z(\%): 322\left(\mathrm{M}^{+}\right)$. Anal. Calcd. for $\mathrm{C}_{16} \mathrm{H}_{10} \mathrm{~N}_{4} \mathrm{O}_{2} \mathrm{~S}$ (322.05): $\mathrm{C}, 59.62 ; \mathrm{H}, 3.13 ; \mathrm{N}, 17.38$. Found: $\mathrm{C}$, $59.51 ; \mathrm{H}, 3.10 ; \mathrm{N}, 17.25 \%$.

2-(4-(2-Oxo-2H-chromen-3-yl)thiazol-2-yl)-2,3-dihydrophthalazine-1,4-dione (15). Yellow solid; m.p. 253-255 ${ }^{\circ} \mathrm{C}$ (Dioxane); IR (KBr): $v 3429(\mathrm{NH})$, 3032, $2928(\mathrm{C}-\mathrm{H}), 1721,1670,1656(3 \mathrm{C}=\mathrm{O}), 1606(\mathrm{C}=\mathrm{N}) \mathrm{cm}^{-1}$; ${ }^{1} \mathrm{H}-\mathrm{NMR}$ (DMSO- $\left.d_{6}\right): \delta 7.37-8.65(\mathrm{~m}, 8 \mathrm{H}, \mathrm{Ar}-\mathrm{H}), 8.36(\mathrm{~s}, 1 \mathrm{H}$, coumarine-H4), $8.64(\mathrm{~s}, 1 \mathrm{H}$, thiazole-H5), 8.87 (s, br, $1 \mathrm{H}, \mathrm{NH}, \mathrm{D}_{2} \mathrm{O}$-exchangeable); $\mathrm{MS} m / z(\%): 389\left(\mathrm{M}^{+}\right)$. Anal. Calcd. for $\mathrm{C}_{20} \mathrm{H}_{11} \mathrm{~N}_{3} \mathrm{O}_{4} \mathrm{~S}(389.05)$ : C, $61.69 ; \mathrm{H}, 2.85 ; \mathrm{N}, 10.79$. Found: C, 61.64; $\mathrm{H}, 2.79 ; \mathrm{N}, 10.58 \%$.

\subsection{Synthesis of Bis-thiazole Derivatives $\mathbf{1 8}$ and $\mathbf{1 9}$}

\subsubsection{Method A}

A mixture of 1,4-dioxo-3,4-dihydrophthalazine-2(1H)-carbothioamide $(\mathbf{1}, 0.221 \mathrm{~g}, 1 \mathrm{mmol})$ and bis- $\alpha$-bromoketones 16 and compound $17(2 \mathrm{mmol})$ in ethanol $(20 \mathrm{~mL})$ was refluxed for $4-7 \mathrm{~h}$ (monitored by TLC). The product started to separate out during the course of the reaction. The solid product was filtered, washed with water, dried and recrystallized from DMF to give the corresponding bis-thiazoles 18 and 19 , respectively.

\subsubsection{Method B}

A mixture of 1,4-dioxo-3,4-dihydrophthalazine-2(1H)-carbothioamide $(\mathbf{1}, 0.221 \mathrm{~g}, 1 \mathrm{mmol})$ and bis- $\alpha$-bromoketones 16 and compound $17(2 \mathrm{mmol})$ in ethanol $(20 \mathrm{~mL})$ was irradiated by an ultrasonic generator in a water bath at $50{ }^{\circ} \mathrm{C}$ for 30-60 min. (irradiation was continued until all of the starting materials have been disappeared and the product was formed, monitored by TLC). The solid that formed after cooling was filtered and recrystallized from DMF to give the corresponding bisthiazoles 18 and 19, respectively.

2,2'-(4,4'-(1,4-Phenylene)bis(thiazole-4,2-diyl))bis(2,3-dihydrophthalazine-1,4-dione) (18). Yellow solid; m.p. $309-311{ }^{\circ} \mathrm{C}$; IR (KBr): v $3427(\mathrm{NH}), 3039,2924(\mathrm{C}-\mathrm{H}), 1669,1648(2 \mathrm{C}=\mathrm{O}), 1610(\mathrm{C}=\mathrm{N}) \mathrm{cm}^{-1}$; ${ }^{1} \mathrm{H}-\mathrm{NMR}\left(\mathrm{DMSO}-d_{6}\right): \delta 7.11-8.02(\mathrm{~m}, 12 \mathrm{H}, \mathrm{Ar}-\mathrm{H}), 8.11(\mathrm{~s}, 2 \mathrm{H}$, thiazole-H5), $8.87(\mathrm{~s}, \mathrm{br}, 2 \mathrm{H}, 2 \mathrm{NH}$, $\mathrm{D}_{2} \mathrm{O}$-exchangeable); ${ }^{13} \mathrm{C}-\mathrm{NMR}$ (DMSO- $d_{6}$ ): $\delta 112.8,116.0,119.2,125.8,128.4,129.5,130.8,131.1,135.3$, 143.8, 148.8, 160.4, 162.8. MS m/z (\%): $564\left(\mathrm{M}^{+}\right)$. Anal. Calcd. for $\mathrm{C}_{28} \mathrm{H}_{16} \mathrm{~N}_{6} \mathrm{O}_{4} \mathrm{~S}_{2}$ (564.07): C, 59.56; $\mathrm{H}$, 2.86; N, 14.89. Found: C, 59.69; H, 2.74; N, $14.75 \%$.

2,2'-(4,4'-(3,4-Dimethylthieno[2,3-b] thiophene-2,5-diyl)bis(thiazole-4,2-diyl))bis(2,3-dihydrophthalazine-1,4dione) (19). Brown solid; m.p. 276-278 ${ }^{\circ} \mathrm{C}$; IR (KBr): v $3429(\mathrm{NH}), 3062,2921(\mathrm{C}-\mathrm{H}), 1670,1652(2 \mathrm{C}=\mathrm{O})$, $1601(\mathrm{C}=\mathrm{N}) \mathrm{cm}^{-1} ;{ }^{1} \mathrm{H}-\mathrm{NMR}\left(\mathrm{DMSO}-d_{6}\right): \delta 2.37\left(\mathrm{~s}, 6 \mathrm{H}, 2 \mathrm{CH}_{3}\right), 7.06-8.07(\mathrm{~m}, 8 \mathrm{H}, \mathrm{Ar}-\mathrm{H}), 8.38(\mathrm{~s}, 2 \mathrm{H}$, thiazole-H5), 9.23 (s, br, $2 \mathrm{H}, 2 \mathrm{NH}, \mathrm{D}_{2} \mathrm{O}-$ exchangeable); $\mathrm{MS} m / z(\%): 654\left(\mathrm{M}^{+}\right)$. Anal. Calcd. for $\mathrm{C}_{30} \mathrm{H}_{18} \mathrm{~N}_{6} \mathrm{O}_{4} \mathrm{~S}_{4}$ (654.03): $\mathrm{C}, 55.03 ; \mathrm{H}, 2.77 ; \mathrm{N}, 12.84$. Found: $\mathrm{C}, 54.86 ; \mathrm{H}, 2.61 ; \mathrm{N}, 12.73 \%$.

\subsection{Agar Diffusion Medium Biological Assays}

All compounds were screened in vitro for their antimicrobial activity, applying an agar diffusion method [34]. A suspension of the organisms was added to sterile nutrient agar media at $45^{\circ} \mathrm{C}$ and the mixture was transferred to sterile Petri dishes and allowed to solidify. Holes of $6 \mathrm{~mm}$ in diameter were made using a cork borer. The samples of the test compounds and of reference drugs, were dissolved in DMSO to give a solution of $5 \mathrm{mg} \cdot \mathrm{mL}^{-1}$. The amount tested of either the synthesized compounds or 
reference drugs was $100 \mu \mathrm{L}$. Dimethylsulfoxide (DMSO) was used as a negative control. The plates were left for $1 \mathrm{~h}$ at room temperature as a period of pre-incubation diffusion to minimize the effects of variation in time between the applications of the different solutions. The plates were then incubated at $37^{\circ} \mathrm{C}$ for $24 \mathrm{~h}$ and observed for antimicrobial activity. The diameters of inhibition zone were measured and compared with those of the reference drugs. The observed inhibition zones were measured in millimeters beyond good diameters. Also, the percentage values of inhibition zones as compared to reference drugs were recorded (Table 4).

\section{Conclusions}

In summary, we have developed a new green methodology and synthesized several novel 2-thiazolylphthalazine derivatives using ultrasound irradiation, resulting in high and efficient yields in short reaction times. The antimicrobial activities of all prepared compounds were evaluated and the results revealed the promising activities of compounds $4 \mathbf{d}, 7 \mathbf{b}$ (117\% zone inhibition), and $7 \mathbf{c}(105 \%$ zone inhibition) against Salmonella sp., exceeding the inhibition zones of the reference drug Gentamycin.

Acknowledgments: The authors wish to thank Taher Salah (Director of Nanotechnology Center, Regional Center for Food \& Feed, Agricultural Research Center) for his support in carrying out the ultrasonic irradiation.

Author Contributions: Fatma S. Elsharabasy, Sobhi M. Gomha and Thoraya A. Farghaly conceived and designed the experiments; Fatma S. Elsharabasy and Sobhi M. Gomha carried out the experiments; Sobhi M. Gomha and Thoraya A. Farghaly analyzed and interpreted the data; Fatma S. Elsharabasy and Thoraya A. Farghaly prepared the manuscript; Heba S. A. Elzahabi performed the biological screening. All authors have read and approved the final manuscript.

Conflicts of Interest: The authors declare no conflict of interest.

\section{References}

1. Cho, J.Y.; Kwon, H.C.; Williams, P.G.; Jensen, P.R.; Fenical, W. Azamerone, a Terpenoid Phthalazinone from a Marine-Derived Bacterium Related to the Genus Streptomyces (Actinomycetales). Org. Lett. 2006, 8, 2471-2474. [CrossRef] [PubMed]

2. Hossain, M.B.; vander Helm, D. Structure of 6-azido-tetrazolo[5,1- $a$ ]phthalazine, $\mathrm{C}_{8} \mathrm{H}_{4} \mathrm{~N}_{8}$, isolated from the toxic dinoflaggelate Gymnodiniumbreve. Acta Crystallogr. C 1985, 41, 1199-1202. [CrossRef]

3. Quan, Z.S.; Sun, X.Y.; Guan, L.P. Synthesis and anticonvulsant activity of 6-alkoxy-[1,2,4] triazolo[3,4-a]phthalazine. Chem. Biol. Drug Des. 2009, 73, 313-319.

4. Gong, P.; Jing-Xion, X.; Yan-Fang, Z.; Juan, L. Synthesis and anticancer activity of novel 1,4-disubstitutedphthalazines. Molecules 2006, 11, 574-582.

5. Gong, P.; Zhang, Y.B.; He, L.; Zhai, X. Synthesis and invitro cytotoxicity of novel 1,4-disubstituted phthalazines. Chin. Chem. Lett. 2008, 19, 29-32.

6. Cardia, M.C.; Distinto, S.; Maccioni, E.; Plumitallo, A.; Sanna, L.; Sanna, M.L.; Vigo, S. Synthesis and characterization of new phthalhydrazothiazole derivatives: A preliminary investigation on their activity against hepatocellular carcinoma. J. Heterocycl. Chem. 2009, 46, 674-679. [CrossRef]

7. Mosaad, S.M.; Goudah, A.; Abotaleb, N.A. Synthesis and anti-inflammatory evaluation of some condensed [4-(3,4-dimethylphenyl)-1(2H)-oxo-phthalazin-2-yl]aceticacidhydrazide. Eur. J. Med. Chem. 2010, 45, 1267-1277.

8. Awadallah, F.M.; Saleh, D.O.; El-Eraky, W. Synthesis vasorelaxant activity, and molecular modeling study of some new phthalazine derivatives. Eur. J. Med. Chem. 2012, 52, 14-21. [CrossRef] [PubMed]

9. Yamaguchi, M.; Kamei, K.; Koga, T.; Akima, M.; Kuroki, T.; Ohi, N. Novel antiasthmatic agents with dual activities of thromboxane A2 synthetase inhibition and bronchodilation. 1.2-[2-(1-imidazolyl)alkyl]-1(2H)phthalazinones. J. Med. Chem. 1993, 36, 4052-4060. [CrossRef] [PubMed]

10. Eguchi, Y.; Sasaki, F.; Takashima, Y.; Nakajima, M.; Ishikawa, M. Studies on Antiatherosclerotic Agents. Synthesis of 7-Ethoxycarbonyl-4-formyl-6,8-dimethyl-1(2H)-phthalazinone Derivatives and Related Compounds. Chem. Pharm. Bull. 1991, 39, 795-797. [CrossRef] [PubMed]

11. Cherkez, S.; Herzig, J.; Yellin, H. Synthesis, saludiuretic, and antihypertensive activity of 6,7-disubstituted1(2H)-and3,4-dihydro-1(2H)-phthalazinones. J. Med. Chem. 1986, 29, 947-959. [CrossRef] [PubMed] 
12. Salvi, V.K.; Bhambi, D.; Jat, J.L.; Talesara, G.L. Synthesis and antimicrobial activity of some 2-[1-(4-oxo-3,4dihydrophthalazine-1-yl)alkyl]-1H-isoindole-1,3(2H)-dione and their imidoxy derivatives. Arkivoc 2006, 14, 133-140.

13. Derita, M.; del Olmo, E.; Barboza, B.; García-Cadenas, A.E.; López-Pérez, J.L.; Andújar, S.; Enriz, D.; Zacchino, S.; Feliciano, A.S. Synthesis, Bioevaluation and Structural Study of Substituted Phthalazin-1(2H)-ones Acting as Antifungal Agents. Molecules 2013, 18, 3479-3501. [CrossRef]

14. AbdEl-Wahab, A.H.F.; Mohamed, H.M.; El-Agrody, A.M.; El-Nassag, M.A.; Bedair, A.H. Synthesis and Biological Screening of 4-Benzyl-2H-phthalazine Derivatives. Pharmaceuticals 2011, 4, 1158-1170. [CrossRef]

15. El-Hashash, M.A.; Guirguis, D.B.; AbdEl-Wahed, N.A.M.; Kadhim, M.A. Synthesis of Novel Series of Phthalazine Derivatives with Antibacterial and Antifungal Evaluation. J. Chem. Eng. Process Technol. 2014, 5, 195-200.

16. Shirai, A.; Fumoto, Y.; Shouno, T.; Maseda, H.; Omasa, T. Synthesis and biological activity of thiazolyl-acetic acid derivatives as possible antimicrobial agents. Biocontrol Sci. 2013, 18, 59-73. [CrossRef] [PubMed]

17. Bretanha, L.C.; Teixeira, V.E.; Ritter, M.; Siqueira, G.M.; Cunico, W.; Pereira, C.M.P.; Freitag, R.A. Ultrasound-promoted synthesis of 3-trichloromethyl-5-alkyl(aryl)-1,2,4-oxadiazoles. Ultrason. Sonochem. 2011, 18, 704-707. [CrossRef] [PubMed]

18. Naeimi, H.; Didar, A. Efficient sonochemical green reaction of aldehyde, thiobarbituric acid and ammonium acetate using magnetically recyclable nanocatalyst in water. Ultrason. Sonochem. 2017, 34, 881-888. [CrossRef] [PubMed]

19. Xavier, D.M.; Goldani, B.S.; Seus, N.; Jacob, R.G.; Barcellos, T.; Paixão, M.W.; Luque, R.; Alves, D. Sonochemistry in organocatalytic enamine-azide[3+2]cycloadditions: A rapid alternative for the synthesis of 1,2,3-triazoylcarboxamides. Ultrason. Sonochem. 2017, 34, 107-114. [CrossRef] [PubMed]

20. Abbas, E.M.H.; Gomha, S.M.; Farghaly, T.A.; Abdalla, M.M. Synthesis of new thiazole derivatives as antitumor agents. Curr. Org. Synth. 2016, 13, 456-465. [CrossRef]

21. Farghaly, T.A.; Gomha, S.M.; Sayed, A.R.; Khedr, M.A. Hydrazonoyl Halidesas Precursors for Synthesis of Bioactive Thiazole and Thiadiazole Derivatives: Synthesis, Molecular Docking and Pharmacological Study. Curr. Org. Synth. 2016, 13, 445-455. [CrossRef]

22. Gomha, S.M.; Riyadh, S.M.; Abdalla, M.M. Solvent-drop grinding method: efficient synthesis, DPPH radical scavenging and anti-diabetic activities of chalcones, bis-chalcones, azolines, and bis-azolines. Curr. Org. Synth. 2015, 12, 220-228. [CrossRef]

23. Gomha, S.M.; Salah, T.A.; Abdelhamid, A.O. Synthesis, characterization and pharmacological evaluation of some novel thiadiazoles and thiazoles incorporating pyrazole moiety as potent anticancer agents. Monatsh. Chem. 2015, 146, 149-158. [CrossRef]

24. Dawood, D.H.; Batran, R.Z.; Farghaly, T.A.; Khedr, M.A.; Abdulla, M.M. New Coumarin Derivatives as Potent Selective COX-2 Inhibitors; Synthesis, Anti-inflammatory, QSAR and Molecular Modeling Studies. Arch. Pharm. Chem. Life Sci. 2015, 875-888. [CrossRef] [PubMed]

25. Farghaly, T.A.; Abdallah, M.A.; Masaret, G.S.; Muhammad, Z.A. New and efficient approach for synthesis of novel bioactive[1,3,4]thiadiazoles incorporated with 1,3-thiazole moiety. Eur. J. Med. Chem. 2015, 320-333. [CrossRef] [PubMed]

26. Gomha, S.M.; Edrees, M.M.; Altalbawy, F.M.A. Synthesis and Characterization of Some New Bis-Pyrazolyl-Thiazoles Incorporating the Thiophene Moiety as Potent Anti-Tumor Agents. Int. J. Mol. Sci. 2016, 17, 1499-1509. [CrossRef] [PubMed]

27. Högberg, L.D.; Heddini, A.; Cars, O. The global need for effective antibiotics: Challenges and recent advances. Trends Pharmacol. Sci. 2010, 31, 509-515. [CrossRef] [PubMed]

28. Farghaly, T.A.; Hassaneen, H.M.E.; Elzahabi, H.S.A. Eco-friendly synthesis and 2D-QSAR study of novel pyrazolines as potential anticolon cancer agents. Med. Chem. Res. 2015, 24, 652-668. [CrossRef]

29. Abbas, E.M.H.; Gomha, S.M.; Farghaly, T.A. Multicomponent Reactions for Synthesis of Bioactive polyheterocyclic Ring Systems under controlled Microwave irradiation. Arabian J. Chem. 2014, 7, 623-629. [CrossRef]

30. Gomha, S.M.; Khalil, K.D. A convenient ultrasound-promoted synthesis and cytotoxic activity of some new thiazole derivatives bearing a coumarin nucleus. Molecules 2012, 17, 9335-9347. [CrossRef] [PubMed]

31. Naock, A.; Schroder, A.; Hartmann, H. Synthesis and spectral characterisation of a series of new heterocyclic triphenyl methane analogues. Dye Pigments 2002, 57, 131-147. [CrossRef] 
32. Sravanthi, T.V.; Pottem, M.R.; Manju, S.L. Design and Synthesis of Bis-Thiazol-2-ylidenes. Asian J. Chem. 2013, 25, 5370-5372.

33. Martin-Cantalejo, Y.; Saez, B.; Soto, J.; Villa, M.J.; Brana, M.F. A New Convergent Synthesis of 4,4'-Bispyridyl-5,5'-Disubstituted-2,2-Bisoxazolesand-Bisthiazoles. Synthesis 2003, 2211-2215. [CrossRef]

34. Cruickshank, R.; Duguid, J.P.; Marion, B.P.; Swain, R.H.A. Medicinal Microbiology, 12th ed.; Churchill Livingstone: London, UK, 1975; Volume II, pp. 196-202.

35. Aggarwal, R.; Kumar, S.; Kaushik, P.; Kaushik, D.; Gupta, G.K. Synthesis and pharmacological evaluation of some novel 2-(5-hydroxy-5-trifluoromethyl-4,5-dihydropyrazol-1-yl)-4-(coumarin-3-yl)thiazoles. Eur. J. Med. Chem. 2013, 62, 508-514. [CrossRef] [PubMed]

36. Cardia, M.C.; Distinto, S.; Maccioni, E.; Bonsignore, L.; DeLogu, A. Synthesis and biological activity evaluation of differently substituted 1,4-dioxo-3,4-dihydrophthalazine-2(1H)-carboxamides and -carbothioamides. J. Heterocycl. Chem. 2003, 40, 1011-1015. [CrossRef]

37. Eweiss, N.F.; Osman, A. Synthesis of heterocycles. Part II new routes to acetyl thiadiazolines and alkylazothiazoles. J. Heterocycl. Chem. 1980, 17, 1713-1717. [CrossRef]

Sample Availability: Samples of the compounds 4, 7, 12-15, 18 and 19 are available from the authors.

(c) 2017 by the authors; licensee MDPI, Basel, Switzerland. This article is an open access article distributed under the terms and conditions of the Creative Commons Attribution (CC BY) license (http:/ / creativecommons.org/licenses/by/4.0/). 